\title{
Capabilities for Innovation: The Nordic Model and Employee Participation
}

1 Peter Nielsen'

Associate Professor, Department of Political Science, Aalborg University, Denmark

I René Nesgaard Nielsen

Associate Professor, Department of Business and Management, Aalborg University, Denmark

I Simon Grandjean Bamberger

PhD Student, Department of Occupational Health, Aalborg Hospital, Denmark

I Jørgen Stamhus

Associate Professor, Department of Business and Management, Aalborg University, Denmark

I Kirsten Fonager

Clinical Associate Professor, Department of Social Medicine, Aalborg Sygehus, Denmark

I Anelia Larsen

PhD, Outpatient Unit, Aalborg Psychiatric Hospital, Denmark

I Anker Lund Vinding

Chief Consultant, Department of Quality and Health, North Denmark Region, Denmark

I Pia Ryom

Leading Psychologist, Department of Occupational Health, Aalborg Hospital, Denmark

\section{I Øyvind Omland}

Associate Professor, Department of Occupational Health, Aalborg Hospital, Denmark

\begin{abstract}
Technological developments combined with increasing levels of competition related to the ongoing globalization imply that firms find themselves in dynamic, changing environments that call for dynamic capabilities. This challenges the internal human and organizational resources of firms in general and in particular their ability to develop firm-specific innovative capabilities through employee participation and creation of innovative workplaces. In this article, we argue that national institutional conditions can play an enhancing or hampering role in this. Especially the norms and values governing relations between employers and employees are expected to be of vital importance. This article will follow a resource-based perspective on developing dynamic capabilities in
\end{abstract}

\footnotetext{
${ }^{1}$ Peter Nielsen, Associate Professor, Department of Political Science, Aalborg University, Fibigerstræde 1, 29, 9220, Aalborg Ø, Denmark, peter@dps.aau.dk, Phone: 9940 8196, Fax: 98155346
} 
order to test the importance of enhancing human and organizational capabilities for innovation in firms. In particular, the article will focus on some of the important institutional conditions in Danish firms derived from the Nordic model, such as the formal and informal relations of cooperation between employers and employees in firms and their function in building capabilities for innovation. The foundation of the empirical analysis is a survey that collected information from 601 firms belonging to the private urban sector in Denmark. The survey was carried out in late 2010.

\section{KEYWORDS}

Dynamic capabilities / Innovation / Globalization / Employee / Employer cooperation / Nordic model

\section{Introduction}

- he Nordic countries have a long tradition of social partners building institutions that regulate industrial relations in multilevel systems, and these institutions have had a profound influence on the specific economic developments in the respective countries (Due et al. 1994, Elvander 2002, Ibsen and Jørgensen 1979). Even though the industrial relations institutions have followed their unique development paths in each of the Nordic countries (Dølvik 2008, Mailand 2009), at the core we find common denominators constituting important principles related to the functioning and capabilities of the Nordic model. First, a comprehensive collective agreements system with coordinated bargaining between the partners at multiple levels; next, employee representation, participation, and cooperation on decisions at various levels; and third, a surveillance system for improving the work environment (Dølvik op. cit. 2008, Jørgensen and Warring 2003, Knudsen 1995, Knudsen et al. 2009). Although the social partners may have shifting and contradicting interests, the three institutional principles are carried by a common interest among the social partners of gaining mutual benefits and minimizing conflicts in the employment relation at the firm level (Strøby Jensen 2007). The industrial relations institutions were originally created as centralized systems, with important macroeconomic and welfare policy functions. However, during the last 25 years there has been a decentralization of the systems in Denmark, enhancing the importance of agreements and initiatives at the firm level (Ibsen and Stamhus 1993, Thörnquist 1999). This institutional development might influence the mutual trust and commitment among the partners, giving the possibilities of mobilizing extra resources inside the individual firm in a context of macroeconomic downturn pressure. The Danish experiences are thus of special interest in relation to decentralized capabilities of the Nordic model.

Parallel to the trend of decentralization of the negotiation and agreement system in Denmark, the globalization of the economy has increased in importance (Markey 2001). Globalization has thus achieved a dominant position in our understanding of the economic context setting, and it has become an important condition for many firms and their employees. The understanding of globalization and its consequences is far from unambiguous. It varies from timid optimism when considering increasing market opportunities to more pronounced worries when the focus is on increased competition, wage levels, and employment prospects. From the angle of the individual firm, globalization means expansion of the conditions that the firm has to cope with strategically, either directly or indirectly. 
The nature of the global economic context, including the technology developments, has placed product or service innovation high on the agenda, both nationally and at the individual firm level. Innovations have become important for firms in order to cope with market fluctuations and create new opportunities (Fagerberg et al. 2005). Product or service innovations may strengthen the economic position of the firm by creating new and perhaps better market opportunities. However, new products or services often mean new ways of organizing the production processes, with increasing demands on flexibility, learning, and competence development of employees (Arundel et al. 2007). Fundamentally, this relates to the importance of developing internal resources and routines to strengthen the ability of the firm to handle changing conditions and exploit shifting market possibilities. The resource-based approach focuses on continuous development of human and organizational resources in a way that strengthens dynamic capabilities for change and results in specific competitive advantages for the firm. Implicitly, this puts the focus on development of innovative capabilities. Basically, however, the precondition for such an approach is active cooperation and commitment from employees at all levels in the firm. Here the institutions of cooperation and co-determination derived from the Nordic model may, directly or indirectly, influence the conditions and behaviors required to develop dynamic and ultimately innovative capabilities in the firm.

The aim of this article is to investigate empirically the extent to which practices of developing human and organizational resources in the firm influence the probability of introducing new products or services on the market, and more specifically which role the formal and informal relations of cooperation and co-determination play in relation to the innovation capability of the firm, under the present economic conditions.

\section{Theoretical framework and hypotheses}

\section{Global economic context}

Globalization has profoundly changed the market conditions for many firms and their employees. Market fluctuations have increased over time, and it has become more difficult to predict their timing, strength, and duration. The impacts of the international business cycles are often strengthened by national sector-specific economic conditions caused by past or present economic policies (Birch Sørensen 2010). Behind the increasing economic fluctuations, global structural developments have taken place that have eroded traditional economic strongholds and given competitive advantages to emerging industrial economies or new markets (Ørestrøm Møller 2010). This has been caused by the combination of global market liberalization and variations of national real economic conditions. For the Nordic countries in general, competition on price has turned into a serious challenge confronting many individual firms, whether international oriented or not. Increasing price competition on the market can be met by strategic measures enhancing productivity by developing the dynamic capabilities of the firm. In this way, internal strengths and weaknesses in general and the ability to mobilize resources in particular are expected to be important for the firm's experience of and ability to cope with price competition, and how price competition is related to competition on quality as well as development of new products. The level of internal dynamic capabilities may also be of importance for the extent to which the firm is able to benefit from technology 
developments in the sector in order to strengthen its competitive position in the market. The global developments and the present economic downturn have thus made it important to consider how the firm evaluates its competitive context, related to the following dimensions:

- Liberalization of international trade

- Technology development in the sector

- General competitive pressure

H1: We expect exposure to pressure from these dimensions to be positively related to the capabilities for innovation in the firm.

\section{Employer and employee cooperation on change and development}

Capabilities for change imply the ability to reconfigure and coordinate mobilization of intangible internal resources in relation to observed or expected changes in the external context (Kirner and Som 2007). In order to perform dynamically, as a precondition such capabilities must have active support, through commitment from as many of the actors inside the firm as possible (Lazonick 1994). The firm has to find ways to build and continuously enforce this commitment in such a way that it facilitates the actors' collective reconfiguration of routines and coordination processes upon which the development of dynamic capabilities rests. The active use of cooperation and co-determination principles and instruments in the Nordic model might, in practice, provide the energy for a climate of commitment to change and innovation in the firm. Another related driver of commitment could be a management style with short power distance between management and employees. Lindell and Arvonen (1997) find empirical support for a Nordic management style that encourages the employees to change, making use of their knowledge and skills in innovation processes. The firm-level participation and cooperation dimensions of the Nordic model have their foundation in the struggle for Industrial Democracy, and thus the instruments of influence are originally of a collective nature. It is instruments appropriate for use in articulating the collective interests of the employees at firm level to obtain influence on management decisions, not only related to the operations of daily work but also on decisions associated with the tactical and the strategic level. The collective nature means that the instruments are operated by representatives elected, on the employee side, to represent the common interests. Complementary to the collective instruments, other more individual-oriented instruments of cooperation have been developed. The origins of these instruments are the management's interest in involving the employees in decisions related to the context of their work. This involvement is founded on theories of human relations, motivations, and resources. Hyman and Mason (1995) theoretically divide the collective and individual-oriented instruments into "Participation" and "Involvement" approaches, relating to the more general Industrial Relations and Employment Relations theories. Thus, Participation represents employees' initiative and interest in having influence on and co-determination in important decisions related to their present and future work situation. Involvement, on the other hand, represents employers' initiative and their interests in building commitment, motivation, and productivity among employees related to their work situation. Hyman and 
Mason's analytical distinction is relevant, but what is even more relevant to investigate is the extent to which the two approaches to cooperation and influence coexist or are even operationally intertwined in firms, as part of the challenge of facilitating change and innovation. Decentralized and holistic responsibilities are important for organizations depending on learning and innovative capabilities. In a study of work organizations in the EU15, Lorenz and Valeyre (2005) found that Danish, Swedish, and to some extent Finnish work organizations are characterized by what is called "discretionary learning." In such a perspective, the focus on the employer and employee cooperation on change and development in the firm should be put on the following dimensions:

- Participation instruments in use

- Involvement instruments in use

- Co-determination patterns

$\mathrm{H} 2$ : We expect the co-determination patterns to be positively related to capabilities for innovation in the firm.

\section{Development of dynamic capabilities}

Globalization and increasingly competitive markets, combined with factor and demand conditions, are considered important for the development of competitive advantages (Porter 1985). However, an exogenously determining perspective on the role of conditions and drivers of competitive advantages cannot stand alone. It has to be complemented with a resource-based perspective, underlining the possibility of the individual firm to act and develop its resources proactively and strategically in such a way that the changing external conditions and opportunities can be sensed and seized (Teece 2007). The resource-based perspective in this way emphasizes the importance of developing specific resources, ensuring competitive advantages for the individual firm in comparison with other firms (Peteraf 1993, Wernerfeld 1984). This perspective of proactive resource development has later been supplemented by the perspective of dynamic capabilities, which stresses the importance of being continuously able to renew and reallocate resources in order to cope with the changing context (Johnson et al. 2009, Teece et al. 1997). A combination of the two perspectives thus implies that firms must be able to renew and develop their unique resources, to be able to maintain competitive advantages in relation to their competitors. Sustainable competitive advantages cannot be based on "standard" resources, such as machines or general skills that are accessible to all firms on the factor markets. Firms have to develop their own internal resources, typically building on their human and organizational resources and in the process having to work with their relations and routines, which is difficult for other firms to observe and thus to imitate. The crucial point is that the resources have to be built in such a way that they can meet the changing market context proactively. Basically, dynamic capabilities are thus defined as the ability to change routines and procedures in order to reconfigure and mobilize the more intangible and tacit resources of the firm.

From a research perspective, it is important to consider how to identify and measure development of dynamic capabilities as intangible and tacit resources in line with the theoretical concepts and relations. To do so, indicators have to catch the relational and 
developmental potentials in a way that covers the dynamic dimensions. A learning perspective on competence development and organization would be a way to meet the dynamic as well as intangible and relational demands of valid and reliable indicators. Competence development configured as mutual learning taking place between employees, involving management, and structured by means of organizational principles, i.e., teamwork and cross-functional or interdisciplinary cooperation, can be characterized as inter-subjective competence development (Jensen and Prahl 2000). The inter-subjectivity is important because it seizes the idea of continuous internalization of collective routines and clues to change such routines in order to meet the changing environment. It is a question of developing meta-routines, which is the core property of dynamic capabilities (Augier and Teece 2008). Closely related to inter-subjective competence development is the idea of the learning organization. The learning organization can be defined as an organization that has been designed in order to maximize the capacity for creating and possessing useful knowledge (Nielsen and Rasmussen 2011). Some structural traits have been found to further both dynamic adaptation and innovation performance (Burns and Stalker 1961, Kanter 1983, Lundvall 2008, Nielsen 2006, Nielsen 2004). The essential importance of dynamic capabilities implies that focus should be put on the dimensions of:

- inter-subjective competence development

- organizational learning configurations

H3: We expect competence development and organizational configurations encouraging learning to be positively related to capabilities for innovation in the firm.

\section{Capabilities for innovation}

As defined above, dynamic capabilities concern meta-routines focused on the abilities to reconfigure and coordinate mobilization of internal resources in relation to observed or expected changes in the external context (Kirner and Som, op. cit.). Depending on the learning and knowledge-creating opportunities embedded in the meta-routines, the dynamic capabilities may promote innovative capabilities. We can define innovative capabilities as the ability to mobilize the human and organizational resources and bring problem-solving ideas that are new to the firm into practical use by implementing them (Kanter 1983). Innovation seen as a result of a process of learning is theoretically appropriate, as it is closely related to the nature of human competences and organizational configurations of the firm (Lam 2010). In principle, innovations may be new products or services, new markets, new technology, organizational developments, or business process development. The main focus is on new products or services, but often the various dimensions of innovation are related (Nielsen 2004). An interesting complement to the question of innovative capabilities is the economic gain from innovations. It is obvious that this is an important side of innovation capabilities: whether they contribute to the economic survival and prosperity of the firm. Capabilities for innovation become the dependent "variable" of the empirical analysis that follows and it focuses on

- strategic priority of innovation dimensions

- product or service innovation 
- economic gain from innovations

Below, the theoretical concepts and relations are put together in a framework that will guide the empirical analysis.

Figure I: Theoretical framework

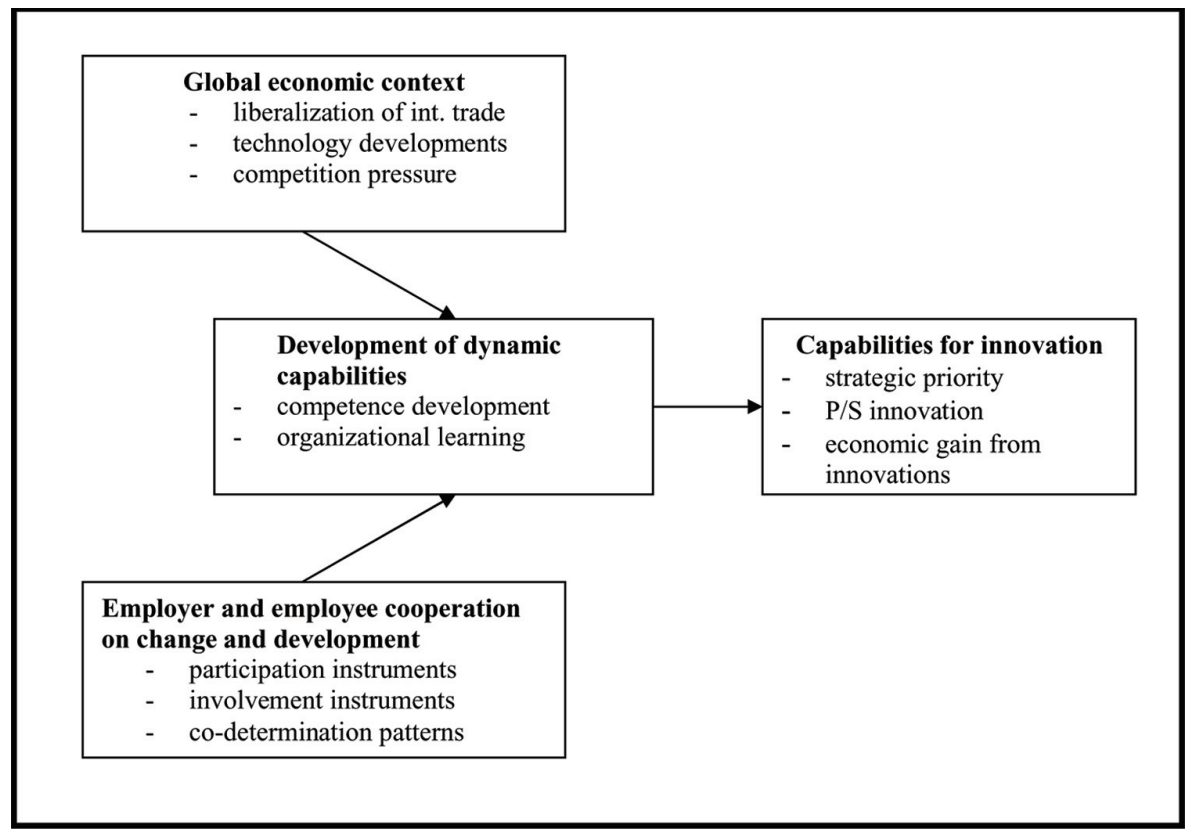

\section{Research method}

The empirical data used in the analysis are collected in a survey carried out in late 2010, the so-called GOPA ${ }^{2}$ survey, which is the last round of a survey panel of firms established in 1996. The first survey in the panel was part of the DISKO $^{3}$ data collection aimed at firms in the private urban sector. This survey resulted in a research sample of 1,900 firms. The next survey was accomplished in 2001 as a matched survey collecting data from employers and employee representatives in 1,363 surviving firms from the first survey, supplemented with a sample in order to avoid bias in the final research sample. The result of this survey round was 2,007 employer responses. In 2006, a new round was completed on the basis of the 1,553 still active firms from the 2001 collection. As in 2001, these firms were supplemented with a sample in order to avoid bias and establish representativity in the final research sample. The result of this collection round was 1,775

\footnotetext{
${ }^{2}$ GOPA is the Danish acronym for Globalization, Transition Pressure, and Psychosocial Work Environment.

${ }^{3}$ The Danish Innovation System: Comparative analysis of challenges.
} 
firms in the research sample. Among these firms, 1,516 were still active in 2010 and they constitute the sample of the GOPA survey. Denmark's Statistics has been in charge of the data collection, and the original panel was verified to 1,430 firms. The data collection resulted in a research sample of 601 firms, which represents a response rate of $39.6 \%$. This response rate is not very satisfying. However, a response analysis broken down on sector and firm size indicates no unacceptable bias. All of the firms that responded are included in the statistical analysis; however, not all questions were completed for every firm; thus, the included number of firms $(n)$ varies in the different analyses.

The GOPA questionnaire collects information on how the management experiences the economic context of the firm, the priorities in the firm of innovation dimensions, realized product or service innovation, and revenue on innovations. However, the core of the questionnaire is on work organizational structures, change, and management practices. In relation to change processes, information is collected on cooperation and co-determination in the firm. Another important set of information collected by the questionnaire concerns human resource practices, flexible working patterns, competence development, and vocational training in the firm. Many of the indicators have been used in the questionnaires since the first survey in the panel (see Nielsen et al. 2011).

The research strategy in the following analysis is deductive, taking its starting point in the theoretical framework developed above and presented in Figure 1. Each main concept in the framework is analyzed empirically, commencing with the "result" concept: capabilities for innovations. The three dimensions of this concept are presented empirically and their relations to the dependent variable, product, or service innovation realized by the firm within a two-year period are analyzed in some detail. The aim has been to give as much empirical insight into the result concept as possible, before starting up the elaborate explanatory analysis of relations between the main concepts and the test of hypotheses. Each of the main explanatory concepts comprises two to three dimensions, which are operationalized as the main indicators. The main indicators are each composed of up to seven individual variables in order to strengthen the validity and reliability of the study. A methodology for constructing scales (Thomsen 2001) has been applied, using principal component analysis to verify the scales. Analytically, the first step has been to present distributions of the individual variables, then verify scale construction by principal component analysis, and finally construct the additive scale or composite indicator. Each of the scales has been tested in logistic regression model with product or service innovation as the dependent variable. In this way, the hypotheses are successively tested, and the reader gets maximum insight into the substance of the measures constructed and used in the statistical models. The aim of this approach has been to perform a differentiated and informative empirical analysis, albeit with high precision, validity, and reliability.

\section{Priorities and capabilities for innovation}

By defining innovative capabilities as the ability to mobilize intangible human and organizational resources and bring problem-solving ideas forward to implementation, it follows that the most central indicator of the resource-based performance should be the firm's 
capability to develop and launch product or service innovation on the market. The capability for innovation is fundamentally a question of generating ideas by managing knowledge from various internal or external sources and materializing the prospects of what is basically new to the firm and perhaps also new on the national or even world market. The capability to innovate is thus an expression of learning processes and knowledge production taking place within the firm, in the interplay between different functional groups and various decision levels. In this way, innovation capabilities are expressions of a more or less conscious strategic coping with the challenges of a turbulent market context. In this perspective, the first step may be to approach innovation as a conscious priority process regarding the use of the firm's resources in new and offensive ways. Operationally, we have asked the firms how they prioritized their innovation efforts in the period 2007-2009.

Table I: Priority given to innovation developments by the firms in the period 2007-2009 (Percent horizontal $\mid n=60 \mathrm{I}$ ).

\begin{tabular}{lcccc}
\hline Developments & $\begin{array}{l}\text { Very high }+ \\
\text { high priority }\end{array}$ & $\begin{array}{l}\text { Middle } \\
\text { priority }\end{array}$ & $\begin{array}{l}\text { Very low }+ \\
\text { low priority }\end{array}$ & $\begin{array}{c}\text { Don't } \\
\text { know }\end{array}$ \\
\hline Product/service & 58.4 & 28.6 & 8.1 & 4.8 \\
\hline Market & 55.7 & 30.6 & 9.0 & 4.7 \\
\hline Technology & 40.8 & 36.8 & 16.3 & 6.2 \\
\hline Organization & 43.9 & 36.9 & 14.8 & 4.3 \\
\hline Business process & 40.6 & 36.8 & 15.9 & 6.7 \\
\hline
\end{tabular}

Development of new products and services was given high priority by a majority of the firms. This majority is double the size of the share of firms giving middle priority to product or service innovation. Less than $10 \%$ of the firms give low or very low priority to product or service innovation. This means that it is on the strategic agenda of most firms. Almost the same pattern can be observed for innovation as market development. This is evidence of the strategic importance of externally related innovations. Technology, organizational, and business process developments are internally related innovations and the three dimensions show similar patterns of priority among the firms. Although they have high priority among many firms, the level is $10-15 \%$ point lower than the externally related innovation. Theoretically, it was expected that the various innovation dimensions associate. In order to test this empirically, a principal component analysis has been performed on the five variables, and the result is that all the innovation priority dimensions load on one single component, with loadings ranging from 0.761 to 0.672 . The result thus indicates that there is one underlying factor, which we could call "firm innovation priority." The five dimensions are all connected to this underlying factor in such a way that more than $53 \%$ of the variation is explained. The loadings in the principal component analysis mean that it is possible to build a single additive scale of "firm innovation priority" that includes information on firms' priorities of all five dimensions on a one-dimensional scale. This "firm innovation priority" scale is shown in Table 2. 
Table 2: Firm innovation priority scale for the period of 2007-2009 (Percent horizontal).

\begin{tabular}{cccc}
\hline High priority & Middle priority & Low priority & $(n)$ \\
\hline 37.4 & 36.3 & 26.3 & 543 \\
\hline
\end{tabular}

The firm innovation priority scale has been arbitrarily divided into three categories, representing the group of firms with high priority to innovation development, the group with middle priority to development, and a group with low priority to innovation development. The question that logically follows from this analysis of priority is to what extent the firms have been able to materialize their priorities and launch new products or services on the market. Table 3 shows to what extent the probability of product or service innovation depends on the priorities given to innovation development in the same period.

Table 3: Product or service innovation introduced on the market by the firms after priority given to innovation development in 2007-2009 (Percent horizontal).

\begin{tabular}{lcccc}
\hline & More than one & One innovation & $\begin{array}{c}\text { No + don't } \\
\text { know* }\end{array}$ & $(n)$ \\
\hline Low priority & 24.5 & 10.5 & 65.0 & 143 \\
\hline Middle priority & 50.3 & 12.7 & 37.1 & 197 \\
\hline High priority & 66.5 & 20.7 & 12.8 & 203 \\
\hline All firms & 49.5 & 15.1 & 35.4 & 543 \\
\hline
\end{tabular}

Chi-sq $p=<0.000 ;$ Gamma $=0.530$

*Response categories of "No" and "Don't know" have been collapsed because the chance of having introduced product or service innovation is considered extremely low when responding "Don't know."

Among all firms, almost 50\% have introduced more than one product or service innovation on the market in the period. Almost $15 \%$ of the firms have introduced one innovation and $35 \%$ say that they have not introduced any product or service innovation in the period, or they do not know. If we observe the distribution after levels of priority given to innovations, it is obvious that there is a strong linear relation between the firms' priority given to innovation development in 2007-2009 and realized products or services on the market in the same period. Among the firms giving high priority to innovation development, two-thirds have actually launched more than one new product or service on the market, and only $13 \%$ have not, or do not know. However, among the firms giving low priority to development, we find almost one-fourth of the firms having introduced more than one innovation and $11 \%$ having introduced one innovation on the market, which is more surprising than the result among the firms with high priority on innovation. This indicates that product or service innovation can be an incremental rather than conscious and strategic incident. In order to follow this perspective, Table 4 shows the shares of product innovations being new on the national market and/or the world market. 
Table 4: Innovations new on the Danish and the world market (Percent in total $\mid n=315$ ).

\begin{tabular}{lcc}
\hline & Not new on world market & New on world market \\
\hline Not new on Danish market & 79.0 & 4.1 \\
\hline New on Danish market & 11.1 & 5.7 \\
\hline
\end{tabular}

Almost $80 \%$ of the products or services launched on the market in the period 20072009 are not new, either on the national market or on the world market. However, the innovations are new to the firm, which means that they are implemented results of learning and resource mobilization efforts. About $11 \%$ of the innovations are new on the Danish market, albeit not on the world market. This share can be classified national innovations. A very small share is known on the Danish market but, according to the firms, new on the world market. This share can be classified as exportable. A share of almost $6 \%$ of the innovations is new on the national as well as the international market. This share can be classified as radical innovations. The degree to which the innovation is radically new is of obvious interest, but what is even more interesting is the economic payoff of the innovation. In Table 5, the relation between revenues on innovation activities and product or service innovation on the market is shown.

Table 5: Revenue on innovation by product or service innovation on the market in 2007-2009 (Percent horizontal).

\begin{tabular}{lccccc}
\hline & Large revenue & Some revenue & Small revenue & No revenue & $(\mathrm{n})$ \\
\hline More than one & 13.2 & 70.0 & 16.4 & 0.4 & 280 \\
\hline One innovation & 14.1 & 52.9 & 31.8 & 1.2 & 85 \\
\hline $\begin{array}{l}\text { No + don't } \\
\text { know }\end{array}$ & 6.4 & 48.1 & 31.6 & 13.9 & 187 \\
\hline All firms & 11.1 & 60.0 & 23.9 & 5.1 & 552 \\
\hline
\end{tabular}

Chi-sq $p=<0.000$ Gamma $=0.428$

Among all firms, the distribution of revenue on innovation activities shows that most typically $60 \%$ of the firms earn some revenue on the innovation activities. Only $11 \%$ earn large revenue as returns and $29 \%$ of the firms earn only little or no revenue on innovation. This distribution is expected to vary according to product or service innovations launched on the market. Observing the distributions for the respective groups of firms introducing more than one, one, and no innovations on the market gives evidence of a variation with significant effect of product or service innovation on revenue. However, the group of firms having introduced one innovation has the highest proportion with large revenue. The group with more than one product or service innovation has by far the largest share of firms with some revenue and also by far the smallest proportion with little or no revenue. This seems to indicate that the economic risk decreases when more than one innovation is introduced on the market. For the group of firms with one innovation, there is still a high risk of earning only little revenue. 


\section{Development of dynamic capabilities and innovation performance}

Mobilizing human and organizational resources within a changing economic context implies focus on competence development. Traditional thinking on competence development implies formalized courses, education, and training. The formalized side of competence development does not lose its importance in dynamic environments focusing on innovation performance. However, if competence developments in the firm are to contribute to the development of dynamic capabilities, it must be tied to the daily routines and, not least, to challenging these routines. Competence development must contribute to building capabilities on how to reconfigurate the routines and practices across disciplines and functions. This means that competence development has to be embedded in the work relations, including the relations with various professions and functions in the firm. In order to get an overview of such inter-subjective competence development activities, we asked about the importance of various conditions that, according to management, are important to ensure that the employees continuously develop their skills.

Table 6: Conditions of decisive and great importance in order to ensure that the employees continuously develop their skills (Percent decisive importance + great importance $\mid n=599$ ).

\begin{tabular}{ll}
\hline Sparring with management/other employees & 50.8 \\
\hline $\begin{array}{ll}\text { Cooperation and networking across divisions } \\
\text { and groups }\end{array}$ & 39.3 \\
\hline Organizing work in teams & 36.8 \\
\hline Planned job rotation & 12.2 \\
\hline
\end{tabular}

Sparring with management and other employees is the least demanding condition in the scope of cross-functional learning. However, if it is used consciously to improve skills across the organization, it may be a basic principle for this kind of competence development. More than half of the firms consider sparring of decisive or great importance to continuously develop employee skills, which means that the principle is extensively used among the firms. Cooperation and networking across divisions and groups are more in line with the idea of the organizational holism in dynamic capabilities, and here almost two-fifths of the firms give high priority to this as a skill development condition. At group level, organization of work in teams also seems to be an important development measure in a large share of firms. Planned job rotation, which is a more individual-oriented measure, has only decisive or great priority among $12 \%$ of the firms. The various conditions of inter-subjective competence development refer to organizational, group, and individual level. In this way, the conditions may be interrelated in the individual firm. The potential interrelation of the development conditions is again explored by a principal component analysis, and the results of the analysis show that the four conditions of continuous skills development all have high loadings, between 0.807 and 0.655 on a single underlying component, which is able to explain $54 \%$ of the variation on the four dimensions. This means that the four conditions are more or less present and 
positively related in the individual firm. The positive and strong relation makes it possible to construct an additive scale of inter-subjective competence development in the firm. The scale is shown in Table 7.

Table 7: Additive scale of inter-subjective competence development conditions (competence). (Percent horizontal).

\begin{tabular}{cccc}
\hline No conditions & I-2 conditions & $3-4$ conditions & $(n)$ \\
\hline 32.2 & 44.7 & 23.0 & 599 \\
\hline
\end{tabular}

The distribution on the scale shows that almost a third of the firms do not consider any of the conditions of continuous skills development of any importance. The majority of the firms mention one or two conditions of importance, and a share of almost one-fourth of the firms mention three or four conditions. This group of firms can be considered as the most advanced in relation to practicing inter-subjective competence development. This scale of inter-subjective competence development is highly correlated to a question of how important it is for the firm's competitiveness that the employees continuously develop their skills, with a significant gamma rank correlation of 0.585 .

Not only are employee competences considered important for the development of dynamic capabilities. Organizational principles supporting the diffusion of knowledge and continuous learning on various levels in the firm may deliver the complementary side of dynamic capability development. In particular, this is expected to be the case if the organization of work ensures responsibility, integrative relations, and active use of employee proposals. In such a perspective, information has been collected on operational use of organizational principles encouraging learning, adjustments, and knowledge diffusion in the firms.

Table 8: Does the firm use the following principles in organizing the work? (Percent of firms using principle $\mid n=60 \mathrm{I}$ ).

\begin{tabular}{ll}
\hline Planned job rotation & $39.1[5.2]$ \\
\hline Autonomous groups & $65.6[22.0]$ \\
\hline Systems for collection of employee proposals & $69.4[23.0]$ \\
\hline Quality circles/groups & $58.9[18.3]$ \\
\hline Delegation of responsibility & $93.2[50.4]$ \\
\hline Interdisciplinary groups & $70.6[19.8]$ \\
\hline Integration of functions & $65.9[14.8]$ \\
\hline
\end{tabular}

[ ] = more than $50 \%$ of the employees included in the organizational principle.

Planned job rotation is found in almost $40 \%$ of the firms, but only a small fraction $(5 \%)$ use this principle for more than half of their employees. Autonomous groups are more frequently used by nearly two-thirds of the firms, and $22 \%$ use it extensively among the 
employees. Systems for collecting employee proposals are used by a slightly higher proportion of firms, and quality circles are used at an almost $10 \%$ point lower level. These organizational principles promote the individual- and group-based use of knowledge and situated learning. If we look at the proportion of firms that delegate responsibility in the organization, it is $93 \%$ and half of the firms delegate responsibility to more than $50 \%$ of the employees. This is an important observation, and it signals consciousness of employees as intangible resources. Most surprising, however, are the shares of firms using interdisciplinary groups and integration of functions. These organizational principles are indications of an integrative organization (Kanter 1983), which has been shown to support innovation performance.

The pattern of occurrence among the firms makes it interesting to investigate the relations between the use of the organizational principles encouraging learning and the complementary inter-subjective competence development in the firms. An analysis shows that each of the organizational principles has significant (Chi-sq $p<0.000$ ) linear correlation with the scale of inter-subjective competence development, showing Gamma coefficients ranging from 0.398 to 0.727 . This supports the point of empirical complementarily between extensity of competence development and each of the organizational principles encouraging learning. These results make it obvious to test whether the organizational principles are structurally related by an underlying learning component. A principal component analysis shows positive loadings between 0.633 and 0.740 on a single component, explaining $46 \%$ of the variation. Again it permits us to construct an additive scale on organizational principles encouraging learning. The result of the scale construction is shown in Table 9.

Table 9: Additive scale of organizational principles encouraging learning (organization) (Percent horizontal).

\begin{tabular}{cccc}
\hline $0-3$ org. principles & $4-5$ org. principles & $6-7$ org. principles & $(n)$ \\
\hline 28.0 & 30.0 & 42.0 & 601 \\
\hline
\end{tabular}

The additive scale has been divided into three categories, representing low, middle, and high extensity in use of the principles encouraging learning. A group of $28 \%$ of the firms use $0-3$ of the principles, a middle category of $30 \%$ of the firms use $4-5$ of the principles, and the highest extensity have more than two-fifth of the firms using 6-7 of the organizational principles. It can be expected that the higher the firms score on the scale, the more conscious they are of encouraging learning and developing useful knowledge. This is confirmed by a correlation analysis showing a highly significant Gamma of 0.508 between the scale of inter-subjective competence development and the scale of principles encouraging learning.

The extensive uses in many firms of principles that can be expected to encourage organizational learning are particularly interesting in the perspective of innovative capabilities. Our theoretically founded hypothesis states that higher learning capacities of the firm are expected to improve capabilities of innovation. We will proceed to the first step in the testing of this hypothesis by exploring the relation between priorities to innovation developments by use of principles encouraging learning in the firm. 
Table 10: Priorities to innovation developments by organizational principles encouraging learning (Percent very high + high priority $n=601$ ).

\begin{tabular}{lccccc}
\hline & Product/service & Market dev. & Technology dev. & Org. dev. & Business dev. \\
\hline 0-3 org. princ & 40.5 & 36.3 & 25.6 & 26.8 & 20.8 \\
\hline 4-5 org. princ & 63.3 & 56.1 & 41.1 & 43.9 & 38.9 \\
\hline 6-7 org. princ & 66.8 & 68.4 & 50.6 & 55.3 & 54.9 \\
\hline Gamma/chi-sq & $0.342 / 0.000$ & $0.392 / 0.000$ & $0.334 / 0.000$ & $0.382 / 0.000$ & $0.449 / 0.000$ \\
\hline
\end{tabular}

Each of the innovation priority dimensions is positive and significantly related to the extent to which the principles encouraging learning are implemented in the firms. However, the table shows two levels rather than three in the distribution. Among the firms having implemented $0-3$ of the learning principles, between $41 \%$ and $21 \%$ give high priority to innovation development. On the next level comprising 4-5 and 6-7 learning principles, between $39 \%$ and $68 \%$ of the firms give high priority to innovation development. This seems to indicate a threshold between the lowest category and the middle and highest use of principles encouraging organizational learning. This observation is used in the analysis below in which a model is tested on realized product or service innovation using the scales of inter-subjective competence development and organizational principles encouraging learning as independent variables.

Table II: Logistic regression on product or service innovation by inter-subjective competence development and organizational principles encouraging learning.

\begin{tabular}{lcccc}
\hline & Effect $(\exp (B))$ & Estimate $(B)$ & Chi-sq (wald) & $P$ value \\
\hline Competence & & & 12.858 & 0.002 \\
\hline Competence $(1)$ & 1.713 & 0.538 & 7.161 & 0.007 \\
\hline Competence (2) & 2.419 & 0.883 & 11.267 & 0.001 \\
\hline Organization & & & 14.951 & 0.001 \\
\hline Organization (I) & 1.825 & 0.602 & 7.062 & 0.008 \\
\hline Organization $(2)$ & 2.344 & 0.852 & 14.392 & 0.000 \\
\hline Constant & 0.653 & -0.426 & 5.641 & 0.018 \\
\hline
\end{tabular}

Results of the model show that in general, the hypothesis can be sustained so far. The first level inter-subjective competence development and the first level of organizational principles encouraging learning have been used as baselines in relation to the effects of level 1 (middle level) and level 2 (highest level). Concerning inter-subjective competence development, use of 1-2 of the competence development conditions gives a significant 1.7 higher chance of product or service innovation, and use of 3-4 of the competence development conditions means 2.4 higher chance of product or service development in the firm, compared with use of no competence development conditions used. Almost 
similar results are found for organizational principles encouraging learning. Here the use of 4-5 organizational principles improves the chances by 1.8 and the use of 6-7 principles enhances chances by 2.3 compared with the use of $0-3$ principles encouraging learning in the firm. A model testing interaction by the two independent variables was also applied but gave no significant result on the interacting links. However, the effects of inter-subjective and continuous competence development as well as the effects of organizational principles encouraging learning - the two dimensions in dynamic capabilities - on innovation performance seem to be statistically confirmed.

\section{Employer and employee cooperation on change and development of dynamic capabilities}

Building and making use of dynamic capabilities in the firm implies frequent incidences of organizational changes and process innovations (Kirner and Som 2007). It implies not only attaining known flexibility patterns but also, and more importantly, the ability of mobilizing new appropriate routines and processes of strategic importance (Teece 2007. The preparedness of prompt organizational and business process change by the actors in the firm is definitely at the core of the concept of dynamic capabilities. A precondition for this preparedness is commitment to the ideas of change and active cooperation among the actors. In this perspective, the decentralized relations of Denmark's Nordic model version may have valuable importance in building and sustaining dynamic capabilities, by continuously confirming the commitment and cooperation among employers and employees. Although the employers have the formal right of management, the frequent use in the firms of organizational decentralization (see Table 8) implies that they acknowledge cooperation and co-determination, which is an important dimension of the Nordic model. We have asked the employers how important they find cooperation with employees in change processes.

Table 12: How important is the cooperation with the employees when making organizational changes in the firm? (Percent vertical $\mid n=600$ ).

\begin{tabular}{lc}
\hline Decisive importance & 39.2 \\
\hline Great importance & 45.0 \\
\hline Some importance & 10.8 \\
\hline No importance & 3.0 \\
\hline Don't know & 1.5 \\
\hline
\end{tabular}

It is evident that a large majority of the employers value cooperation with employees. Only 3\% do not ascribe cooperation on change processes of any importance, and $11 \%$ declare some importance to cooperation. The most typical response is great importance, which is stated by $45 \%$ of the firms, but at almost the same frequency level, $39 \%$ ascribe cooperation on change processes decisive importance. The question that logically follows is how the firms make use of this willingness of the employers to acknowledge the impor- 
tance of internal cooperation. Basically, it is a question of utilization of human resources as a source of knowledge and experience in the process of change. The answer can be indicated by asking at what stage in the change process the employees are involved.

Table 13: At which phase in the change process is the employee representative and/or the employees concerned involved? (Percent vertical $\mid n=600$ ).

\begin{tabular}{ll}
\hline Idea phase & 34.5 \\
\hline Decision phase & 24.7 \\
\hline Implementation phase & 32.5 \\
\hline No involvement & 4.2 \\
\hline Don't know & 4.2 \\
\hline
\end{tabular}

If part of the aim of involvement is to establish a collective ownership to the changes and furthermore to build learning- and development-oriented cultures among the employees in the firm, the expectations should be that involvement takes place in the early phases of the change process. The early involvement establishes a precondition for co-determination on practical solutions of the problems the firm confronts. The early involvement also makes better use of the knowledge on practical problems, processes, and challenges that the employees possess. Ceteris paribus, this should result in better - i.e., more valid and reliable - decisions. The table shows that more than one-third of the firms involve the employees in the early idea phase. This is an indication of the willingness to use the knowledge resources of the employees in the change process. One-fourth of the firms include employees in the decision phase, which also gives the possibility of delivering strategic or tactic input to the change process. A little less than one-third of the firms involve the employees in the implementation phase. The importance of involvement at this stage should not be understated. Often implementation gives possibilities of discretionary influence on the practical function and behavioral consequences of the change project. Although the figures only deliver what could be called a superficial "phase picture" of employee involvement, they seem to indicate that a precondition for mobilizing human resources in the dynamics of change processes is present in many firms in this area, which is of fundamental importance when developing dynamic capabilities.

The insights into the importance of cooperation stated by the employers, together with the pattern of involvement of employees in change processes, make it relevant to proceed to the question of what channels of communication are used in the cooperation between employers and employees on change processes. Theoretically, it has been discussed how the channels of communication and cooperation can be divided into indirect or institutional channels involving elected employee representatives and direct channels involving the employees concerned by the changes or all employees in the firm. The first type of cooperation was named "Participation," and the latter type "Involvement" (Hyman and Mason 1995). Use of the various channels is revealed by answers to the question on how the cooperation between employer and employees is arranged in relation to change processes in the firm. Table 14 shows the results. 
Table 14: How is the cooperation between management and employees arranged in relation to internal change processes in the firm? (Percent responding "high degree" + some degree $\mid n=600$ ).

\begin{tabular}{ll}
\hline Employee representative participates in management meetings & 22.8 \\
\hline Within the cooperation committee & 33.6 \\
\hline Employee representative on firm's board & 17.7 \\
\hline Project groups with management and employees & 53.1 \\
\hline Common meetings with employees concerned & 74.0 \\
\hline Common meetings with all employees & 63.6 \\
\hline
\end{tabular}

It is obvious from the response pattern that the direct channels - the involvement channels - are used most frequently by the firms. Meetings with the employees concerned by the change are by far the most typical channel of cooperation, used by almost three-fourths of the firms. Next we find meetings with all employees, and third project groups with management and employee representatives. It can be argued that this channel belongs to the "participation" category. However, the employee representatives in project groups may be "commoners," meaning that they are not formally elected to represent their colleagues in the institutionalized channels. Looking at the institutionalized "participation" channels, it is obvious that they are actively used in many firms. The cooperation committees are used in one-third of the firms. Employee representative on management meetings is used in $23 \%$ of the firms and representatives participating in the firm's board are used in $18 \%$ of the firms. This broad pattern of cooperation channels in use inspired us to explore whether certain channels are used together and others are used more as single instruments. In order to unveil this, a principal component analysis has been performed using oblimin rotation. The result is presented in the table below.

Table 15: Principal component analysis of cooperation channels used in change processes (Factor loadings higher than 0.600 marked with bold).

\begin{tabular}{lcc}
\hline & $\begin{array}{c}\text { Comp I: } \\
\text { Involvement }\end{array}$ & $\begin{array}{c}\text { Comp 2: } \\
\text { Participation }\end{array}$ \\
\hline Employee representative participates in management meetings & 0.271 & $\mathbf{0 . 6 6 8}$ \\
\hline Within the cooperation committee & 0.346 & $\mathbf{0 . 7 9 0}$ \\
\hline Employee representative on firm's board & 0.312 & $\mathbf{0 . 7 6 \text { I }}$ \\
\hline Project groups with management and employees & $\mathbf{0 . 6 3 5}$ & 0.487 \\
\hline Common meetings with employees concerned & $\mathbf{0 . 8 9 6}$ & 0.352 \\
\hline Common meetings with all employees & $\mathbf{0 . 8 5 6}$ & 0.292 \\
\hline
\end{tabular}

Extraction Method: Principal Component Analysis.

Rotation Method: Oblimin. 
The principal component analysis shows a pattern of two components after oblimin rotation. The loadings of the individual channels on the components support a structural division between a participation component, including employee representative on management meetings, cooperation committee, and employee representative on the firm's board, and an involvement component embracing meetings with all employees, meetings with employees concerned, and project groups with management and employee representatives. It is quite interesting and remarkable that the last-mentioned involvement channel loads almost as much on the participation component. This is in line with the more theoretical considerations stated above. Observing how the channels load on each of the component, we may expect a correlation between the components. This is confirmed in a correlation analysis showing a correlation coefficient of 0.418 between the two components.

Building on the results from the principal component analysis, two additive scales have been constructed, supplying a one-dimensional scale of participation summing the three dimensions, and a one-dimensional scale of involvement summing the other three dimensions. The idea is to test a relation between the two cooperation principles and the question on whether the opinion of the employees has furthered or hampered the change processes.

Table 16: Use of participation channels and effects on organizational development of common employees' opinion towards changes (percent horizontal).

\begin{tabular}{lcccc}
\hline & Furthered & Hampered & Neither-nor & $(n)$ \\
\hline No channels in use & 34.5 & 6.1 & 59.4 & 261 \\
\hline One channel in use & 50.6 & 6.7 & 42.7 & 164 \\
\hline Two channels in use & 50.0 & 7.6 & 42.4 & 92 \\
\hline $\begin{array}{l}\text { Three channels in } \\
\text { use }\end{array}$ & 54.8 & 6.5 & 38.7 & 31 \\
\hline Total & 43.1 & 6.6 & 50.4 & 548 \\
\hline
\end{tabular}

Chi-sq $p=<0.009$, Gamma $=-0.248$

The analysis of the relation between the use of participation channels and the effects of employees' opinions on organization development processes is significant with a moderate correlation. Observing the distribution in the table, it is obvious that the number of channels in use do not have any effect on the share of firms mentioning that the employees' opinion has hampered organization development. However, it is interesting to see how the use of channels influences the share mentioning that employees' opinion furthers the organization development. This means that the use of participation channels does not remove the hampering effect but promotes furthering effects on organizational development. The following table will show whether the effect is similar for the use of involvement channels.

The table shows an even stronger and highly significant effect of employees' opinion furthering organizational development depending on how many involvement channels have been in use. From a share of $21 \%$ among the firms using no involvement channels, the share of firms using three channels increases to $50 \%$. The increase between shares 
Table 17: Use of involvement on channels and effects on organizational development of common employees' opinion toward changes among employees (percent horizontal).

\begin{tabular}{lcccc}
\hline & Further & Hamper & Neither-nor & $(\boldsymbol{n})$ \\
\hline No channels in use & 20.8 & 5.2 & 74.0 & 77 \\
\hline One channel in use & 39.1 & 2.3 & 58.6 & 87 \\
\hline Two channels in use & 46.3 & 8.0 & 45.7 & 175 \\
\hline Three channels in use & 50.0 & 7.6 & 42.4 & 210 \\
\hline Total & 43.0 & 6.6 & 50.5 & 549 \\
\hline
\end{tabular}

Chi-sq $p=<0.000$, Gamma $=-0.269$

having a furthering effect on organizational development is linear and increases from $21 \%$ to $39 \%$ by using one channel, $46 \%$ by using two channels, and $50 \%$ by using three channels. On the other hand, there is no regular pattern among the shares of firms mentioning hampering effects. Here we find a marginal increase in the shares after number of channels in use, but the shares are of minor size compared with the shares furthering the development processes.

Until now, the analysis has concentrated on the motivation, phase of involvement, and channel of cooperation, and we have not yet considered which subjects the change processes concerned. The subject areas of the decisions are definitely important in a dynamic capability perspective. To get a closer view of co-determination on specific subject areas, we have asked the employers whether the employee representative or the employees are involved in decisions regarding internal organization changes, new technology, new products or services, and human resources strategies. Some of these decisions may be of strategic nature and some are more tactic or operational, but the explicit involvement in decisions means a degree of co-determination for the employees in the subject area.

Table 18: Inclusion of employee representatives or employees concerned in decisions regarding: (Percent horizontal $\mid n=60 \mathrm{I}$ ).

\begin{tabular}{lccc}
\hline & $\begin{array}{c}\text { Both employee } \\
\text { representative and } \\
\text { employees concerned }\end{array}$ & $\begin{array}{c}\text { Either employee } \\
\text { representative or } \\
\text { employees concerned }\end{array}$ & $\begin{array}{c}\text { No inclusion } \\
\text { in decision }\end{array}$ \\
\hline Organizational change & 10.1 & 50.9 & 38.9 \\
\hline New technology & 9.2 & 67.9 & 23.0 \\
\hline New products or services & 2.8 & 69.6 & 27.6 \\
\hline HR strategies & 5.8 & 46.6 & 47.6 \\
\hline
\end{tabular}

The table shows that the employees concerned or their representatives are involved in decisions to a varied degree, depending on the subject matter. Most frequently, the employees concerned or their representatives are involved in decisions on new technology, 
but involvement in product or service innovation decisions is almost as frequent. Involvement in decisions on HR strategies is the least frequent, but even here we find more than $50 \%$ of the firms involving either employees concerned or their representatives or both. It is most common that either employee representatives or employees concerned participate, and the shares where both the representatives and employees concerned participate are all smaller than $10 \%$ down to $3 \%$ regarding new products or services. As for the use of cooperation channels, it is of interest to explore whether firms practice multiple co-determinations or the involvement is more narrow or divided. We have deployed a method similar to the method used above in order to test for an underlying component which the individual dimensions relate to. Results of the principal component analysis show high loadings $(0.778-0.700)$ of the dimensions on a single component explaining $52 \%$ of the variation. This means that the co-determination dimensions are practiced empirically by the firms in a manner that legitimates building an additive one-dimensional scale of co-determination by including information on the use of the four decision dimensions. The scale has been divided into a category representing narrow co-determination, which includes none or one single dimension, a category representing medium co-determination, representing two or three dimensions, and a category representing inclusive co-determination on all four dimensions.

Table 19: Additive scale on degree of co-determination on decisions in the firm (co-determination) (Percent horizontal).

\begin{tabular}{cccc}
\hline Inclusive & Medium & Narrow & $(\boldsymbol{n})$ \\
\hline 36.9 & 44.1 & 19.0 & 601 \\
\hline
\end{tabular}

The additive scale shows that most of the firms include either employees concerned or employee representatives in more than one of the decision dimensions included in the scale. The typical co-determination is medium level, but more than one-third of the firms are in the inclusive category involving either employees concerned or employee representatives or both in all four subjects of decision. To test a possible effect of medium or inclusive co-determination on product or service innovation in the firm, a model has been applied that includes the scales of competence development and organizational principles encouraging learning together with the scale of co-determination.

Table 20: Logistic regression on product or service innovation by organizational principles encouraging learning, inter-subjective competence development, and co-determination.

\begin{tabular}{lcccc}
\hline & Effect $(\exp (B))$ & Estimate $(B)$ & Chi-sq (wald) & $P$ value \\
\hline Organization & & & 9.481 & 0.009 \\
\hline Organization (I) & 1.600 & 0.470 & 4.013 & 0.045 \\
\hline Organization (2) & 2.050 & 0.718 & 9.359 & 0.002 \\
\hline Competence & & & 10.927 & 0.004 \\
\hline
\end{tabular}




\begin{tabular}{lcccc}
\hline & Effect $(\exp (B))$ & Estimate $(B)$ & Chi-sq (wald) & $P$ value \\
\hline Competence $(1)$ & 1.645 & 0.497 & 6.011 & 0.014 \\
\hline Competence $(2)$ & 2.291 & 0.829 & 9.661 & 0.002 \\
\hline Co-determination & & & 5.159 & 0.076 \\
\hline Co-determination (I) & 1.724 & 0.544 & 4.928 & 0.026 \\
\hline Co-determination (2) & 1.620 & 0.482 & 3.460 & 0.063 \\
\hline Constant & 0.489 & -0.715 & 10.292 & 0.001 \\
\hline
\end{tabular}

Results for the effect of development of dynamic capabilities are parallel to the results found in the model presented in Table 11. Using 4-5 of the learning principles (1) enhances the chances of product innovation with 1.6, and 6-7 principles (2) implemented in the organization means two times higher chances of product or service innovation compared with 0-3 principles implemented. In line with these effects, inter-subjective competence development conditions give the effect of 1.6 for 1-2 conditions (1) used, and 2.3 for 3-4 conditions (2) used in the firm. The effect of co-determination on product or service innovation is present; however, at the baseline as well as at the inclusive level it is not significant at the $5 \%$ level. The significance levels are very close to the $5 \%$ level (0.076 and 0.063$)$, and with a relatively small sample the effects are worth taking into consideration. We have analyzed the bivariate relation between co-determination and the two dimensions of dynamic capabilities. The analysis shows strong significant linear relations with Gamma coefficient of 0.355 for competence development and 0.439 for organizational learning principles. This means that the relation between employer and employee cooperation and development of dynamic capability can be sustained. In the next section, we will investigate the complete framework in a single model.

\section{Global economic context and capabilities for innovation}

During the last decade, the global economy has been through an exceptional business cycle, going from growth with high pressure on existing capacity, to downturn with financial crisis, followed by a serious slump. The setback in the Danish economy has been severe and first of all a result of the financial crises and the following drop in export possibilities and consumer demand in general (Birch Sørensen 2010). On firm level, this shift from a booming economy in the mid-zeros to the dramatic drop in demand on international as well as national markets represents the conditions of a rapidly changing environment that follows from increasing globalization. But how did the individual firms experience this global economic cycle? We have asked the firms whether the financial crisis has changed their market situation, and the response pattern is presented in Table 21.

Sales on the national market have been much deteriorated by the financial crises for one-fourth of the firms, and $43 \%$ has experienced some deterioration. This means that more than two-thirds of the firms have experienced deteriorations on the national sales markets due to the financial crises. Less than one-fourth of the firms did not experience any change, and only $3.5 \%$ have improved their market situation. A somewhat similar 
Table 21: Has the financial crises changed the firm's possibilities for: (Percent horizontal | $n=600$ ).

\begin{tabular}{lcccccc}
\hline & $\begin{array}{c}\text { Much } \\
\text { improved }\end{array}$ & $\begin{array}{c}\text { Somewhat } \\
\text { improved }\end{array}$ & No change & $\begin{array}{c}\text { Somewhat } \\
\text { deteriorated }\end{array}$ & $\begin{array}{c}\text { Much } \\
\text { deteriorated }\end{array}$ & Don't know \\
\hline $\begin{array}{l}\text { Sale on the national } \\
\text { market }\end{array}$ & 0.5 & 3.0 & 24.0 & 42.6 & 24.5 & 5.5 \\
\hline $\begin{array}{l}\text { Sale on the interna- } \\
\text { tional mkt. }\end{array}$ & 0.2 & 3.3 & 32.5 & 22.3 & 11.5 & 30.2 \\
\hline Finance & 0.5 & 1.2 & 52.8 & 25.2 & 12.3 & 8.0 \\
\hline Liquidity & 1.0 & 4.0 & 49.5 & 27.8 & 12.2 & 5.5 \\
\hline Recruitment of labor & 18.2 & 49.5 & 25.0 & 3.2 & 0.8 & 3.3 \\
\hline
\end{tabular}

pattern can be found for consequences of sales on the international market, however, with approximately half the shares of firms having their sales much or somewhat deteriorated, compared with the distribution for sale on the national market. A larger share of almost one-third of the firms did not experience any changes. Among these would be the home market firms, typically experiencing the international crisis indirectly on decreasing national markets. Access to financial capital for investments has been on the public agenda as a serious consequence of the financial crisis. About $38 \%$ of the firms saw their possibilities deteriorate somewhat or much in relation to this, and more than $50 \%$ are not affected. Not surprisingly, we find less than $2 \%$ of the firms having their situation improved. A more or less similar pattern can be observed for access to liquidity, where a marginally higher share of firms finds their situation either deteriorated or improved. The consequence of the financial crisis on recruitment of labor is almost the opposite as for sales on the national market. More than two-thirds of the firms have experienced improvements in the recruitment situation, and one-fourth did not experience any changes. Only 4\% of the firms have experienced deteriorations. In general, the pattern shows that a majority of the firms have experienced deteriorations on the sales markets, and less than half of the firms are hit by finance or liquidity deteriorations. Due to decreasing demand on the markets, the labor market was weakened and it has thus been easier for many firms to recruit employees. However, the main line of consequences of the financial crisis for the firms is status quo and deteriorations, and since then the crisis has continued to develop toward a serious downturn. This might have an impact on competition, which can be expected to have been strengthened on all parameters.

Table 22: To what extent does the firm at present (2010) encounter competition? (Percent horizontal $\mid n=601 / 600 / 600$ ).

\begin{tabular}{lccccc}
\hline & $\begin{array}{c}\text { High } \\
\text { degree }\end{array}$ & $\begin{array}{c}\text { Some } \\
\text { degree }\end{array}$ & $\begin{array}{c}\text { Small } \\
\text { degree }\end{array}$ & $\begin{array}{c}\text { Not } \\
\text { at all }\end{array}$ & $\begin{array}{c}\text { Don't } \\
\text { know }\end{array}$ \\
\hline Product/service prices & 53.7 & 33.9 & 6.2 & 1.7 & 4.5 \\
\hline Product/service quality & 20.8 & 44.3 & 24.3 & 3.8 & 6.7 \\
\hline Development of new prod/serv. & 14.2 & 42.0 & 28.5 & 4.5 & 10.8 \\
\hline
\end{tabular}


As expected, the firms typically encounter a high degree of competition, but it is first of all in relation to the prices of products or services that the competition is severe. More than half of the firms experience price competition to a high degree, and one-third of the firms to some degree. This means only $8 \%$ are little or not affected by price competition. Looking at the competition on quality, $44 \%$ of the firms are affected to some extent, but the share of firms experiencing high degree of competition is a little more than one-fifth. This is less than the share that is exposed only to a small degree or not at all to competition on quality. A possible explanation of this pattern could be that many firms give high priority to quality systems, i.e., quality circles or systems for collecting employee proposals (see Table 8 above), which means that the competition is not felt so severe on this parameter. We can observe the pattern even more pronouncedly for competition on innovation. Here $56 \%$ of the firms experience high or some degree of competition. The decreasing pattern of competition measured on the three parameters raises the question whether complementarity exists inside the firms between these competition parameters. A principal component analysis shows that all three parameters have high loadings on one single component (loadings between 0.901 and 0.834). This result allows construction of a single additive scale on present competition (Nukonk) measuring the degree of competition that the firms are exposed to.

Competition pressure is to be expected as one of the main consequences of globalization (Lundvall and Kristensen 1997). Above all, this is caused by liberalization of international trade and indirectly by technology development. In order to explore how these developments are sensed by the firms, we have asked to what extent liberalization of international trade has had consequences for the development in their competition circumstances. The answers are presented in Table 23.

Table 23: To what degree has liberalization of international trade influenced developments in the competition encountered by the firm in the period 2007-2009: (percent horizontal | $n=597 / 596 / 596)$.

\begin{tabular}{lccccc}
\hline & $\begin{array}{c}\text { High } \\
\text { degree }\end{array}$ & $\begin{array}{c}\text { Some } \\
\text { degree }\end{array}$ & $\begin{array}{c}\text { Small } \\
\text { degree }\end{array}$ & $\begin{array}{c}\text { Not } \\
\text { at all }\end{array}$ & $\begin{array}{c}\text { Don't } \\
\text { know }\end{array}$ \\
\hline Product/service prices & 14.1 & 20.8 & 25.0 & 24.3 & 15.9 \\
\hline Product/service quality & 6.7 & 21.5 & 28.9 & 26.5 & 16.4 \\
\hline Development of new prod/serv. & 5.5 & 20.3 & 29.9 & 26.3 & 18.0 \\
\hline
\end{tabular}

Again we observe that price competition to a higher degree than the two other competition parameters causes competition pressure for the firms. One-third of the firms has stated that liberalization of trade to a high or to some degree has influenced their competition circumstances. However, almost $50 \%$ of the firms stated that liberalization of trade either to a small degree or not at all has influenced price competition. This is even more pronounced for the quality and innovation competition. Here a majority $(55-56 \%)$ of the firms state that their competition conditions only to a small degree or not at all have been affected by liberalization of international trade.

Table 24 shows the distribution of responses to the question on the impact of sectorspecific technology development on competition development. The distribution approxi- 
Table 24: To what degree has the sector-specific technology development influenced the development of the competition encountered by the firm in the period 2007-2009: (percent horizontal $\mid n=599 / 598 / 598)$.

\begin{tabular}{lccccc}
\hline & $\begin{array}{c}\text { High } \\
\text { degree }\end{array}$ & $\begin{array}{c}\text { Some } \\
\text { degree }\end{array}$ & $\begin{array}{c}\text { Small } \\
\text { degree }\end{array}$ & $\begin{array}{c}\text { Not } \\
\text { at all }\end{array}$ & $\begin{array}{c}\text { Don't } \\
\text { know }\end{array}$ \\
\hline Product/service prices & 10.0 & 32.2 & 35.1 & 11.7 & 11.0 \\
\hline Product/service quality & 7.7 & 32.3 & 36.8 & 12.2 & 11.0 \\
\hline Development of new prod/serv. & 8.0 & 31.8 & 35.5 & 11.9 & 12.9 \\
\hline
\end{tabular}

mates a normal distribution for all three parameters, with the highest frequencies for some degree and small degree of impact and "tails" on high degree and not at all. This indicates that the technology development in the sector is recognized to a certain degree as important for competition on prices, quality, and innovation, but it is not particularly salient. Liberalization of trade and technology developments is the main incident of globalization, but to what extent are they experienced as complementary inside the individual firm? We will answer this question by means of a principal component analysis of the six parameters together.

Table 25: Principal component analysis of influence of liberalization of international trade and sector-specific technology development (Factor loadings higher than 0.600 marked with bold).

\begin{tabular}{lcc}
\hline & Comp I: Likonk & Comp 2:Tekonk \\
\hline Liberalization comp: Prices & $\mathbf{0 . 9 5 2}$ & 0.480 \\
\hline Liberalization comp: Quality & $\mathbf{0 . 9 6 7}$ & 0.517 \\
\hline Liberalization comp: Innovation & $\mathbf{0 . 9 4 6}$ & 0.534 \\
\hline Technology comp: Prices & 0.521 & $\mathbf{0 . 9 4 0}$ \\
\hline Technology comp: Quality & 0.507 & $\mathbf{0 . 9 6 3}$ \\
\hline Technology comp: Innovation & 0.484 & $\mathbf{0 . 9 3 2}$ \\
\hline
\end{tabular}

Extraction Method: Principal Component Analysis.

Rotation Method: Oblimin.

The principal component analysis shows an underlying structure of two components, which together explains $90 \%$ of the variation. Even though the structure of the two components is evident, it is also clear that the components are positively related. The analysis shows a positive correlation of 0.532 , which can be considered as strong. However, as the results of the principal component analysis indicated, there are two components in the latent structure, and thus two additive scales have been constructed: one additive scale on impacts of trade liberalization on competition environment (Likonk) and the other on impact of sector-specific technology developments on competition environment 
(Tekonk). Together with the additive scale on the present competition pressure, we are now in a position to analyze the impacts of globalization and competitive pressure on innovation capability. This is done in a model that includes the relevant indicators on co-determination and development of dynamic capabilities. In this way, the model tests the dimensions in the general theoretical framework presented in Figure 1.

Table 26: Logistic regression on product or service innovation by organizational principles encouraging learning, inter-subjective competence development, co-determination, Nukonk, Likonk, and Tekonk.

\begin{tabular}{lcccc}
\hline & Effect $(\exp (B))$ & Estimate $(B)$ & Chi-sq (wald) & $P$ value \\
\hline Organization & & & 6.710 & 0.035 \\
\hline Organization (I) & 1.494 & 0.402 & 2.877 & 0.090 \\
\hline Organization (2) & 1.841 & 0.610 & 6.592 & 0.010 \\
\hline Tekonk & & & 22.294 & 0.000 \\
\hline Tekonk (I) & 1.911 & 0.647 & 7.129 & 0.008 \\
\hline Tekonk (2) & 2.966 & 1.087 & 22.241 & 0.000 \\
\hline Co-determ*Comp & & & 13.358 & 0.010 \\
\hline Co-determ (I)*Comp (I) & 1.955 & 0.671 & 7.644 & 0.006 \\
\hline Co-determ (I)*Comp (2) & 2.439 & 0.892 & 5.793 & 0.016 \\
\hline Co-determ (2)*Comp (I) & 1.704 & 0.533 & 3.822 & 0.051 \\
\hline Co-determ (2)*Comp (2) & 2.206 & 0.791 & 5.734 & 0.017 \\
\hline Constant & 0.398 & -0.921 & 17.658 & 0.000 \\
\hline
\end{tabular}

The model uses a forward selection method and the last third step is presented in the table. First of all, it can be noted that present competition pressure and liberalization of the competitive environment has been excluded from the model as insignificant. Among the global context factors, only the impacts of sector-specific technology developments on competition environment have been included in the final model. Also the indicator of co-determination has been excluded as a single variable, but what is more interesting is that it is included in interaction with competence development. This means that with medium and inclusive co-determination, the presence of 1-2 or 3-4 inter-subjective competence development conditions produces from 1.7 to 2.4 higher chance of product or service innovation, compared with a baseline of no co-determination and no inter-subjective competence development dimensions. Also organizational principles encouraging learning have positive and significant effects on learning in this model. The chances of product or service innovation in the firm are 1.4 higher with 4-5 learning principles implemented, and 1.8 higher with 6-7 learning principles implemented, compared with a baseline with 0-3 principles implemented. The included context factor of sector-specific technology developments impact on competition has a relatively high effect, which means that medium impact on competition enhances chances with 1.9 
and maximum impact on competition enhances chances with 2.9. In general, the model shows that a competitive environment is important for product or service innovation in the firm specifically through sector technology development and that learning organization principles also deliver significant higher chances of innovation. Co-determination is important in interaction with the other dimensions in the development of dynamic capabilities, which is competence development. Inter-subjective competence development is again of importance both for the individual employee and for the organization's innovation performance. In this way, co-determination has a key position as a catalyst of performance development, both for the employer and for the firm.

\section{Discussion and conclusion}

The article has analyzed empirically the important question of innovation capabilities in Danish firms. Innovation, learning, and knowledge development are considered of great importance, not least in an international competitive environment (Kuo 2011). The importance makes it interesting to consider analytically the drivers of capabilities for innovation. The article has studied these drivers from two angles. One angle has been the international and national competitive environment as a driver. Here the economic context sets the frame for the possibilities and challenges considered decisive for the development of competitive advantages for firms (Porter 1985). Applying this angle, we expected exposure to liberalization of trade, technology development in the sector, and present competitive pressure to be positively related to capabilities for innovation in the firm. The other angle has been the national institutional conditions of norms and values governing relations between employers and employees at the firm level. These are institutional conditions derived from the Nordic model of cooperation between the social partners. In applying this angle, we expected the co-determination pattern to be positively related to capabilities for innovation in the firm. To our knowledge, the two angles have not before been analyzed together in relation to capabilities of innovation in Danish firms. This has legitimated a thorough and sometimes explorative empirical analysis including stepwise relations between several dimensions. The angles could be analyzed and tested as competing explanations. We have chosen, however, to analyze the angles in a more complementary framework, in order to investigate which of the dimensions are important for capabilities of innovation. At the core of the framework, we have placed the development of dynamic capabilities. This extension of the resourcebased perspective stresses that the firms have the possibilities to develop their internal intangible resources in order to cope strategically with the challenges of the context. An important point is that change in the context calls for dynamic resources and capabilities. Empirically, the analysis is embedded in such a situation of change from a booming economy to financial crisis and recession, which is expected to challenge the dynamic element. More operationally, we therefore expect competence development and organizational configurations encouraging learning to be positively related to capabilities for innovation in the firm. In the following, we will discuss the empirical findings from the two angles applied and the importance of developing dynamic resources for innovative capabilities.

Capabilities for innovation is the dependent variable of the empirical analysis in the article. A large part of the firms have launched innovations on the market within the 
two-year period in focus. Half of the firms have introduced more than two new products or services on the market, and only a little more than a third of the firms did not innovate products or services in the period. Being product or service innovative can be a result of a strategic priority process or a result of a more incremental process. The analysis shows that there is a strong linear relation between the priority given to innovation by the firm and realized product or service innovations. Often innovation and economic performance are implicitly related, and it is assumed that innovations are beneficial for economic revenue. This assumption has been analyzed, and the result is that the chances of some or even large revenue is significantly present, but there is certainly also a risk. The analysis seems to give evidence that the economic risk deceases when more than one innovation is introduced on the market.

Mobilization of human and organizational resources is expected to be crucial for innovative capabilities, and our main hypothesis concerning this is that we expect competence development and organizational configurations encouraging learning to be positively related to capabilities for innovation in the firm. Using competence development as an indicator for building dynamic capabilities demands an analysis of the relational aspects of skill development. The term inter-subjective competence development is applied for this perspective. The measures of inter-subjective competence development practiced refer to the individual, group, and organizational level in the firm. Analytically it is shown that the various levels are related to the same underlying component, and a single scale is then constructed. Complementary to the conditions of inter-subjective and continuous development of employee skills is the organizational principles supporting diffusion of knowledge and learning in the firm. Those are the structural dimensions of the learning organization (Lundvall and Nielsen 2007). The empirical indicators cover responsibility, discretion, autonomy, quality, inter-disciplinarity, and integration. Most of these principles are extensively used in the firms, and one of them - delegation of responsibility - is used intensively by a little more than half the firms. Complementarities between the organizational principles are further confirmed by a latent structure analysis of the organizational principles, showing high positive loadings on a single component. The scales of inter-subjective competence development and organizational principles encouraging learning are tested in a model with product or service innovation as dependent variable. This model tests competence development and organizational configurations encouraging learning to be positively and significantly related to capabilities for innovation in the firm. The effects of the two scales on innovation capabilities are almost identical, which means that our expectations can be sustained.

Changes in the firm require cooperation, trust, and commitment in order to meet objectives. Here the firm-level relations, derived from the Nordic model, may contribute toward building and sustaining a culture of trust, commitment, and acknowledgement of complementary resources. To explore the climate of cooperation as a context for the co-determination behavior, we have asked how important the employers find cooperation with employees in change processes. From the responses, it is evident that a large majority of the employers appreciate cooperation with their employees in situations of change. This is in line with the result on how the firms make use of their employees' resources in various phases of the change processes. Closely related to this cooperation discussion is the question of which type of channels are used in communication on the 
change processes. Participation channels are most related to the institutional side of the Nordic model and Involvement channels to new management principles (Nielsen 2004). However, new management principles and use of the Involvement channels need not be in contradiction with institutional cooperation and use of Participation channels. The question of either Participation or Involvement has been analyzed thoroughly in the article, and the results show that Involvement channels are used more frequently than the Participation channels. The analyses further reveal that the dimensions belonging to each of the two types of channels are behaviorally related, but also that there is a strong correlation between the two ways of communication, represented by Participation and Involvement. Furthermore, the analysis has shown that both types of channels have positive linear effect on employees' opinion toward changes in the firm. The inclusion of employee representatives or employees concerned varies empirically according to subject areas, but an analysis of the underlying structure of co-determination shows high loadings on a single component of co-determination. To test the effects of co-determination on process or service innovation, a model was applied, showing that co-determination had positive effects, although not significant on $5 \%$ level. However, bivariate analyses on relations between co-determination and each of the two dynamic capability scales show strong and significant correlations. In this way, we can expect co-determination to have only an indirect effect on innovative capabilities.

Turning analytically to the angle of international or national competition environment as driver for innovation capabilities, we have focused on how the Danish firms have experienced the financial crisis. In general, a majority of the firms have experienced more or less deteriorations on the sales markets, and it is on the national market that the largest share of firms find their situation much deteriorated. In relation to finance and liquidity, half of the firms did not experience any change, and less than half had their situation worsened. In relation to the labor market, the situation was the reverse, with surplus of labor caused by a drop in demand for products or services. Deteriorations on national and international markets would logically have impact on competition pressure, and a large majority of the firms typically encounter a high degree of competition, especially on prices. Decreasing shares of firms experience a high degree of competition on quality or on product innovation. The optimistic interpretation would be that more firms feel stronger competitive advantages on these parameters, compared with price competition. In the globalization perspective, we have two main indicators, which is liberalization of international trade and sector-specific technology development. The scales of competitive context are applied in a model that also includes all the other scales developed previously and test their effects on product or service innovation. The final model thus tests the complete theoretical framework by applying all the relevant dimensions. Results of this test show that only the impact of sector-specific technology developments is significant among the dimensions of the competitive environment angle. Another, and perhaps the most interesting, result is that co-determination only has significant effect in interaction with inter-subjective competence development. Logically, this makes sense as the inter-subjective approach to competence development as precondition needs cooperation, trust, and commitment, which the decentralized aspects of the Nordic model may deliver. We can then conclude that a milieu of cooperation and co-determination is of relevance in building dynamic capabilities and realizing them as capabilities for innovation. 


\section{References}

Arundel A., Lorenz E., Lundvall B.-A. and Valeyre A. (2007): 'How Europe’s economies learn: a comparison of work organisation and innovative mode for the EU-15', Industrial and Corporate Change 16(6): 1175-1210.

Augier M and Teece D. J (2008): 'Strategy and evolution with design: the foundation of dynamic capabilities and the role of managers in the economic system', Organisation Studies 29(8-9): 1187-1208.

Birch Sørensen P. (2010): ['The downturn in the Danish economy: How much was selfinflicted'], Samfundsøkonomen 1: 29-34 (in Danish).

Burns T. and Stalker G. M. (1961): The Management of Innovation. London: Tavistock.

Due J., Madsen J. S., Jensen C. S. and Petersen L. K. (1994): The Survival of the Danish Model. København: Dansk Jurist og Økonom Forlag.

Dølvik J. E. (2008): 'The Negotiated Nordic Labor Markets: From Bust to Boom', Center for European Studies Working Paper Series 162.

Elvander N. (2002): 'The labour market regimes in the Nordic countries: a comparative analysis', Scandinavian Political Studies 25(2): 117-137.

Fagerberg J., Mowery D. C. and Nelson R. R., eds. (2005): The Oxford Handbook of Innovation. Oxford: Oxford University Press.

Hyman J. and Mason B. (1995): Managing Employee Involvement and Participation. London: Sage.

Ibsen F. and Jørgensen H. (1979): [Trade Union and State] (Vol. I and II). København: Gyldendal. (in Danish).

Ibsen F. and Stamhus J. (1993): [From Centralized to Decentralized Determination of Remuneration] København: Dansk Jurist- og Økonom Forlag (in Danish).

Jensen I. and Prahl A. (2000): [Competence as an intersubjective phenomenon] In Andersen T. et al. (eds.) [Competence in an Organizational Perspective] Roskilde Universitets Forlag (in Danish).

Johnson G., Scholes K. and Whittington R. (2009): Fundamentals of Strategy. Harlow: Pearson.

Jørgensen C. H. and Warring N., eds. (2003): [Democracy and participation in working life] Roskilde: Roskilde Universitetsforlag (in Danish).

Kanter R. M. (1983): The Change Masters. London: Unwin.

Knudsen H. (1995): Employee Participation in Europe. London: Sage.

Knudsen H., Busck O. and Lind J. (2009): [The effect of employee participation on the working environment quality] Aalborg: Institut for Samfundsudvikling og Planlægning (In Danish).

Kuo T. H. (2011): 'How to improve organizational performance through learning and knowledge', International Journal of Manpower 32(5/6): 581-603.

Lam A. (2010): 'Innovative organizations: structure, learning and adaptation', Innovation Perspective for the 21st century, Madrid, BBVA: 163-175.

Lazonick W. (1994): Business Organization and the Myth of the Market Economy. Cambridge: Cambridge University Press.

Lindell M and Arvonen J. (1997): The Nordic management style in a European context', International Studies of Management and Organisation 26(3): 73-91.

Lorenz E. and Valeyre A. (2005): 'Organisational innovation. HRM and labour market structure: a comparison of the EU15', Journal of Industrial Relation 47(4): 424-442.

Lundvall B.-Å. (2008): Innovation and Competence Building in the Learning Economy - Implications for Innovation Policy. Aalborg: Kunnskabsdugnaden 2008.

Lundvall B.-Å. and Kristensen F. S. (1997): 'Organizational change. Innovation and human resource development as a response to increasing competition', DRUID Working Paper 97-16. Aalborg: Aalborg University. 
Lundvall B.-Å. and Nielsen P. (2007): 'Knowledge management and innovation performance', International Journal of Manpower 28(3/4): 207-223.

Mailand M. (2009): Corporatism in Denmark and Norway - yet another century of Scandinavian corporatism? WSI Mitteilungen - Monatzeitschrift des Wirtschafs- und Sozialwissenschaftlichen Instituts in der Hans-Böckler Stiftung 1/2009.

Markey R. (2001): Models of Employee Participation in a Changing Global Environment: Diversity and Interaction. Aldershot: Ashgate.

Nielsen P. (2004): [Human Resources in the Knowledge Economy - Innovation. Knowledge Organization and Skill in the New Millennium] Aalborg: Aalborg Universitetsforlag (in Danish).

Nielsen P. (2006): The Human Side of Innovation Systems - Innovation, New Organization Forms and Competence Building in a Learning Perspective. Aalborg: Aalborg Universitetsforlag.

Nielsen P. and Rasmussen P. (2011): 'Knowledge management in the firm: concepts and issues', International Journal of Manpower 32(5/6): 479-493.

Nielsen P., et al. (2011): ['Ready for Globalization? On developments in Danish firms to meet the challenges of globalization - a dynamic resource perspective'], Tidsskrift for Arbejdsliv 13(3): 12-29 (in Danish).

Ørestrøm Møller J. (2010): [The crisis' long-term impact on economic and political balance in the world] Samfundsøkonomen 1. København: Dansk Jurist- og Økonom Forlag (in Danish).

Peteraf M. A. (1993): 'The cornerstones of competitive advantage. A resource-based view', Strategic Management Journal 14(3): 179-191.

Porter M. E. (1985): Competitive Advantage: Creating and Sustaining Superior Performance. New York: Free Press.

Som O. and Kirner E. (2007): ‘The resource-based view of the firm'. Contribution to Nielsen et al. Multi-level Theoretical Framework. http://www.meadow-project.eu/index.php?/ Article-du-site/Background-documents.html

Strøby Jensen C. (2007): [Industrial Relations in Denmark - From Conflict-Based Consensus to Consensus-Based Conflict] København: Dansk Jurist- og Økonomforlag (in Danish).

Teece D. J., Pisano G. and Shuen A. (1997): 'Dynamic capabilities and strategic management', Strategic Management Journal 18(7): 509-533.

Teece, David J. (2007): “Explicating Dynamic Capabilities: The Nature and Microfoundations of (Sustainable) Enterprise Performance," Strategic Management Journal, 28(13): 1319-1350.

Thomsen S. R. (2001): The Methodology for construction of scales. Aarhus: Department of Political Science.

Thörnquist C. (1999): 'The decentralization of industrial relations: the Swedish case in comparative perspective', European Journal of Industrial Relations 5(1): 71-87.

Wernerfeld B. (1984): 'A resource-based view of the firm', Strategic Management Journal 5(2): 171-180. 